\title{
SUCCESS IN LEARNING ENGLISH AS A FOREIGN LANGUAGE
}

\author{
Nihta V. F. Liando \\ Faculty of Languages and Arts, Manado State University \\ e-mail: nihta02@yahoo.com
}

\begin{abstract}
Abstrak
Penelitian ini bertujuan untuk memaparkan bagaimana berbagai kejadian dalam proses pembelajaran mendukung para pembelajar meraih keberhasilan dalam belajar bahasa Inggris sebagai bahasa asing. Data penelitian diambil dari pengalaman-pengalaman pribadi dari tiga orang mahasiswa dan tiga orang dosen pada jurusan Pendidikan Bahasa Inggris Universitas Negeri Manado. Wawancara semi terstruktur dan narasi pribadi digunakan untuk mengumpulkan data dalam penelitian ini. Ada tiga tema utama yang dapat disimpulkan dari data wawancara yaitu: keluarga dan masyarakat, pengaruh lembaga (institusi), dan faktor-faktor individu. Temuan penelitian ini menunjukkan bahwa anggota-anggota keluarga, guru dan individual memegang peranan penting dalam mendukung para pembelajar sehingga bisa berhasil dalam pembelajaran bahasa Inggris
\end{abstract}

Kata kunci: bahasa Inggris sebagai bahasa asing, pembelajaran yang berhasil, motivasi pribadi.

\section{INTRODUCTION}

The research literature in the area of second language learning suggests that motivation is one among several factors that play an important role in learning a second language (Crookes \& Schmidt, 1991; Dornyei, 1994a, 1994b; Ely, 1986; Gardner \& Lambert, 1972; Laine, 1978, 1988; Morris, 2001; Oxford \& Shearin, 1994). However, what maybe important to explore is the other factors beyond motivation that lead some students to work harder and become more successful.

Indonesia has adopted English as a tool of communication to establish relationships with other countries. English, despite its status as a second language, has become more and more popular among scholars, bureaucrats and the elites in Indonesia as the use of information technology is increasing. This has been called the era of autonomy in Indonesia. The rapid change is expected particularly because of Indonesia's role in the ASEAN Free Trade Association (AFTA). However, the excitement of developing English as a second language of communication in Minahasa is paralleled by the fear of losing the languages of Minahasan, which form part of the people's identity. The languages have been used by ancestors, and they characterize the Minahasan people as different from other ethnic groups in Indonesia. What is needed, therefore, is an appropriate method for teaching English, which will both contribute to meeting the needs of people as a part of a global community without displacing their identity.

Many teachers and educators view English teaching as a neutral practice. However, teaching English cannot be seen as a neutral practice given the cultural and political assumptions embedded in it. Norton (1989), for example, examined how teachers and 
learners of English attempted to resolve the ambivalent role of English in South Africa. English in South Africa became a political tool especially during the period when discrimination against black South Africans was dominant. She concluded that applying communicative competence as the base of the teaching of English could give students freedom to choose what was more appropriate and useful for them. Canagarajah (1993) distributed questionnaires and interviewed 22 tertiary-level Tamil students attending a mandatory class of English for general purposes (EGP) in Sri Lanka. The findings showed students' motivation for learning English declined gradually based on the record of attendance, but the results of the interview and questionnaire showed that they gave a high priority to the learning of English.

Canagarajah suggested that these dual attitudes to English appeared because of the conflict students faced in maintaining their own identity and the desire for socioeconomic gain. Therefore, cultural factors and socioeconomic are among the many factors that may contribute to students' decision to study a language (Lin, Wang, Akamatsu, \& Riazi, 2002; Norton \& Toohey, 2001).

In Indonesia, English as a second language is taught in schools. Following a classification by Krashen (1981), Clyne (1986), and Ellis (1994) on the contexts of learning languages other than the mother tongue, English in schools is taught through instructional learning. According to Ellis (1994) this means learning via study with guidance from reference books or direct classroom instruction of interest has been teachers and students' motivation to study this kind of instructional context. Motivation doesnotalwayscomefrom theindividual. Tremblay and Gardner (1995) who studied 75 students in a francophone secondary school who completed a range of motivational measures such as the variables mentioned above and the existing measures of attitudes and motivation. Findings revealed that these new motivational measures such as roles of parents and teachers influenced students' language learning achievement. Findings of Laine's study (1978) indicated the important role of parents towards students' success in learning a foreign language. In addition, Le Blanc (1997) described the importance of positive perceptions of language learning in the community, especially among parents as a motivating factor in students' learning. Several studies of motivation have been able to identify teachers' roles as significant factors in learning second languages (Ellis, 1994; Macaro, 1997). Gardner, Smythe, Kirby and Bramwell (1974) identified teacher, and school course of the target language (TL) among the factors that promoted second language acquisition. This project was conducted to gather information directly from the language learners regarding their experience of learning English and to identify motivations, socioeconomic and cultural factors might influence their desire to learn. Drawing from the participants' life experiences in learning English, I gathered data regarding students' and teachers' beliefs about 1) the qualities contribute to a student becoming a good student and 2) the teaching practices contribute to a lecturer becoming a good teacher.

\section{RESEARCH DESIGN}

Participants were purposively selected. Lecturers in the English Department at Manado State University were selected based on their teaching experience. The different length of their working experience meant that it was possible to gather a range of stories 
about their experience with English in different eras of teaching, as well as their opinions about the issues being addressed in this study. One female and two male lecturers were selected and coded as Dan, Mista, and Mien for L1, L2 and L3 respectively. Dan is a senior lecturer and has been in service for more than 30 years. He will retire in three or four years. Mista took up a position as a junior lecturer in the English department in 2001. Mien has been in the department for approximately 20 years.

The students who participated in this study were in their final year and were writing-up their skripsi, a report which is similar to an honours thesis. When the interviews were held, they were in their $8^{\text {th }}$ semester. They all started their study in the English department UNIMA in 2005. These student participants were coded as Helly, Deysa, and Yenta for S1, S2, and S3 respectively. Helly attended a general high school and took the Language program. Deysa attended a general high school too but took the Natural Sciences program. Yenta attended a vocational high school and took a Secretarial program.

The aim of this pilot study was to gather baseline information from lecturers and students regarding their perceptions of the qualities that contribute to a student becoming a good student and the teaching practices that contribute to a lecturer becoming a good teacher. The data was collected through interviews designed to gather information about past actions and how individuals understood the actions (White, 1973). In addition to the interviews, student participants were asked to write their own stories about learning English. Stories, according to Labov (1972), serve to tell specific past events and have common properties. "How events have been constructed by active subjects" can be identified in the narratives (Riessman, 1993, p.70). Thus their stories help to give a detailed picture of their experience in learning English in addition to the information gathered in the interviews. These stories were used as supporting information. Only students were asked for stories and due to health problems, only two student participants submitted narratives.

The interview tapes were transcribed using punctuation to support the meaning of the utterances rather than the structure of the talk (Mills, 2001). The transcripts were then examined and categorized into key themes (Mills, 2001).

\section{RESULTS AND DISCUSION Result}

Three key themes were identified in both the student and lecturer interviews. These were family and community, institutional influences, and individual factors. In this section the student data and the lecturer data are discussed through these key themes.

The first theme, family and community encompassed the comments of participants regarding the support of family members and the media in their initial experience with English prior to junior high school. It also included comments about the influence of the media on their learning. 
Figure 1. The three key themes generated from the interview

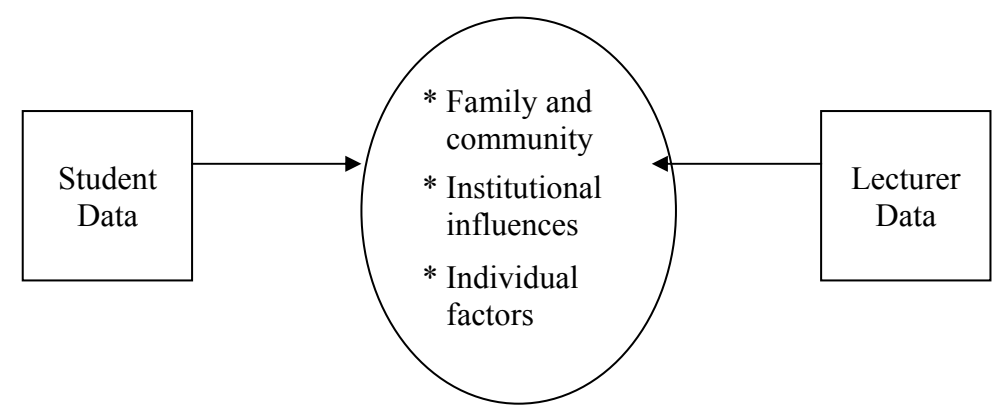

Key Theme: Family and Community

\section{Student Data}

All student participants were introduced to English when they were approximately 12 years old. At this age, they were still at the elementary school level. In the Indonesian school system, English was officially introduced in junior high school. The way each of these participants was introduced to English varied. Helly knew English through her cousin, as she said:

Helly: hhm, he just told me about greetings, like, good morning, good afternoon, and then hello ‥

She admitted that at first she did not like English but her cousin gave her encouragement so she then began to like English:

Helly: I mean, I know English but before that time I don't like it, but after my cousin give the support that English is good, so I learn English.

Deysa's mother was an English teacher and she was introduced to English by her mother through songs. She indicated:

Deysa: I knew English from the book, esp. from the song like: "Are you sleeping?", "There is the window" ... My mother taught me, because you know my mother is an English teacher so she has some books about English especially for junior high school so I learnt it.

Unlike Helly and Deysa, Yenta learned about English from her brother: Yenta: my brother taught me several English songs. At that time I started to like English.

As well as family support, growing up with access to technology gave participants more opportunity to be in touch with English through media telecommunication, in this case television. The participantsall mentioned watching films on TV, as typified in the following extracts.

Yenta: When I was in elementary school, when watching English films.

And also Helly as follows:

Nihta: or, probably, did you like watching films

Helly: yes I like

Nihta: yes? Oh that's why you know about English?

Helly: yes

At that time, most TV programs, especially cartoons and films were in English. They were not dubbed into Indonesian. Deysa mentioned that because her mother, as an English teacher, had a collection of English 
books, she could access those books and learned the words and pictures and the way to pronounce the words. She noted:

Deysa: ... when I was in elementary school, in studying English, I memorize the vocabulary. In the book, there were the words, the picture and how to pronounce the words so I learnt it myself, only simple words. But sometimes I asked my mother and she taught me.

Helly also mentioned learning English through a book given by her cousin. She remarked:

Helly: He gave me one book ... [an] English book for junior high school. I don't remember the author. I just remember the name of the book. He asked me to make one sentence but just a simple sentence and ask me to memorize about five sentence[s] or five words that I have learned, for example, the first sentence that I made that is, I have a belt.

The students' comments showed that family and the media helped them to become familiar with English.

Parents played an important role in determining the participants' choice of study. For example, Helly mentioned that her mother supported her to study in the English department and to become an English teacher:

Helly: ... my mother support[ed] me to be a teacher

Deysa also mentioned the discussion she had had with her parents when she decided to move from the Civil Engineering faculty to the English department:

Deysa: ... On the $3^{\text {rd }}$ semester in Civil Engineering faculty I moved to the English department. After a long consideration, I talked to my father ...
Yenta commented on the influence of her parents when she finished junior high school and wanted to continue to a senior high school:

Yenta: Actually I would like to study in Manado (capital city of the province) but my father and my mother didn't allow me to study in Manado.

After she finished a senior high school, it was her mother's suggestion to study in the English department. Yenta wrote in her narrative: "I took [the] English program as suggested by my mother that English is important for the future". In terms of becoming a successful language learner, Yenta mentioned the role of parents in motivation:

Yenta: The students' parents, maybe. They should give motivation to their children.

The stories told by these students showed parental influences in the decision making of their children.

\section{Lecturer Data}

All lecturer participants mentioned the involvement of family and community in their learning English experience in different ways. Although Dan had no English experience prior to his junior high school, he mentioned his family's influence:

Dan: I think they were a bit helpful in advising me to learn English but as long as my father as a teacher. So I live in a family where education in family work quite okay ... Probably because during that time my parents, they speak Dutch, they spoke Dutch at home. So, when being introduced by another second language it was really not a different thing, that's one thing.

Mien mentioned the role her father played in introducing her to English as follows: 
Mien: Well, what I remember is when I was at home, my father tried to make me remember again what had been taught in school, so he tried to make me, I don't know whether in his mind to make me better than the others, I don't know, but it was out of my thinking, because just seeing from the experience after teaching at school, he tried also to bring the materials home and he tried to teach that again to me, again and again, maybe that's the point that all the words, all the songs were memorized at that time.

Mien's parents also took charge in determining her future, for example she described how she entered a Sekolah Pendidikan Guru (a kind of teacher training school) after she finished junior high school. This decision was very much influenced by her parents who wanted her to be a teacher, to continue the family tradition, to follow her father profession as a teacher. Being an "obedient child", and the oldest of four, she felt, she carried this responsibility to be a good example for her younger siblings. So, she was sent to this school and lived in a school dormitory while she was studying:

Mien: Actually, I can say that I'm one of the obedient children because I was once told that I need to be a teacher, my father told me that they need me to be teacher, I don't know, maybe my father wants me to be a teacher. You know, my father wants me to continue his profession, I don't know, but finally, off the record, just kidding maybe, but it was kept well in my mind and finally I considered to continue my study in SPG and when I told my parents, they were very, very happy. Both my parents, father and mother took me to Tomohon to have a test and then after that I lived for three years in dormitory, so just going back to my village when I had holiday.

The encouragement she received from her family gave her a lot of support and helped her to concentrate and study hard when she faced hard times in university due to lack of English learning in high school:

Mien: And I once came to my decision, I had to move from here and I wrote a letter to my parents that I planned to move to the faculty of Theology because of, you know, my experience, it was very hard for me to adjust with my friends, especially the friends I mentioned before, because of Maxi, Ronny, and Hamid from Ternate. But my father replied my letter and said if other people can do that why not you, so, he tried to motivate me and I finally concentrate again and at the second or the third semester, because of my hard work, I even went to sleep in two or three $o^{\prime}$ clock in the morning.

Mien also mentioned about the importance of family support:

Mien: Yes, the family also. Even though the learners have the motivation but if there's no support from his or her environment, say the family it's also hard for him to increase his or her knowledge in English, the mastery of English. And also the facility from the family, so the support from the family is important also in helping the learn master English.

Unlike the other participants, Mista who attended elementary school in the 80 s, had the opportunity to learn 
English from his older friends:

Mista: ..., I just heard it from some seniors but I didn't study it yet. Yeah, I just know first but I didn't learn it.

He was also motivated by his female friend in the senior high school:

Mista: I got one friend when I was in senior high school. At that time I was so impressed by her fluency. And I think if she could do that, of course I can do the same.

These comments show the role of family and community in the learning English experience of these lecturer participants.

\section{Key Theme: Institutional Influences Student Data}

The next key theme, institutional influences, focuses on comments about both students and lecturer experiences in learning English when they were at school as well as their opinions about the role of institutions in English teaching in terms of the teacher's performance, materials, methods and teaching practices. All participants mentioned and clearly remembered their English teacher when they were asked how they learned English in junior high school. They were also asked to recall the good things about those teachers. For example:

Yenta: My teacher, at that time is $\mathrm{Mr}$ Widodo and Mrs Mamengko. I like them, the way they taught ... I like English because the teacher is very good. It is easy to follow for example when they teach simple present tense. When they teach reading, they read it and translate it.

Deysa also indicated similar opinions about her teacher:

Deysa: He introduced the lesson which is very interesting for us. He is a nice person and is very kind and the important thing is if he knew someone is very interested in learning English he will give motivation to learn ... I can say that my English teacher is very good in junior high school and senior high school. He's very good in teaching.

According to these participants, the teacher was an influential factor in developing interest and enthusiasm for English, especially when learning English in junior high school for the first time.

When the participants were asked about factors contributing to someone being a successful language learner and the practice of English teaching, the factors mentioned were the teacher and the teaching methods, and techniques and the teaching aids, the teacher used. For example:

Deysa: There are so many factors. Like, a good teacher, he or she must be able to intrigue or stimulate the students to be interested in learning English. Maybe the first one, he or she must be able to apply various methods or techniques... Aids, it can be visual or audio visual.

Helly: Well, I think, first it depends on the teacher what kind of techniques or methods in variation in teaching ... that's from the teacher's side.

Yenta: I think, the first is the teacher. The teacher should master the material and give motivation to students... they have to prepare the materials, using methods and approaches... the teacher should use methods which is suitable with the materials.

Yenta mentioned the necessity of a teacher and students working together actively, as she mentioned: 
Yenta: The students should also help the teacher, so both of them should be active.

School was also mentioned in regards to successful English teaching practices. Deysa gave one example of the school as giving more opportunities to English to be developed in its environment:

Deysa: I found in some junior high schools in Manado, they gave more for English subject. For example, they put it in MULOK (local-content subject), or the other one, maybe the school can make a club in English (English club), something like that, so the students who are interested in learning English, they put it in one and they are given motivation.

The government was also considered to be an influential factor in making the teaching English practices a success, as follows:

Helly: For the government, I think they make library especially English book, lots of English book, not from Indonesia but the government should import from another countries in order to add our knowledge.

Deysa: Maybe they should give enough attention to curriculum and syllabus. The books include interesting topics to be discussed.

\section{Lecturer Data}

Mien who had learned English in elementary school mentioned that it was the initiative of the teacher who motivated her:

Mien: You know when I was in elementary school, it was 1972 or 73 , I was at the 6 grade. One of my teachers introduced me (class) English by showing pictures and vocabulary and for me it was very interesting. And I felt it was very interesting because it was very new for me and it was the first experience in my life knowing English. And then it was very easy for me to memorize the words and, I don't know whether I am classified as ahh, I can say I have the interest in English, I don't know, but that was the first experience knowing English.

Nihta: So, was English taught in the elementary school at that time?

Mien: No, it's just the creativity of the teacher, actually, just to, I don't know why we have that kind of material and beside that we have also, it started from songs actually. He taught some songs in English and after that the teacher taught some vocabularies and refer us to memorize the words well. And I did it well. I memorize all the words.

Nihta: It's very interesting right ...

Mien: Because it's not in the curriculum.

At that time, in the early 70s and attending an elementary school in a small village, the experience of actually learning English in the school classroom was something rare.

When Mien was in junior high school, the teacher who taught her English had a background in physics but his teaching impressed her:

Mien: Ok, as we know that in our condition in Indonesia, English is taught from secondary school, in this case in junior high school. And my school was in the head of district, ibukota kecamatan, it was in 1975, maybe if I'm not Mistaken, I was first taught by the teacher from, what I mean to say that, the teacher didn't have 
the knowledge of English also. But you know what his way of teaching me English was very, very understandable. And then from that point I tried to say that, I don't know whether it was already formed before that, when I was in elementary school but when I came to junior high school, I was in my conclusion that English was very interesting, once again, that teacher had the background of physics, if I'm not Mistaken, yes science, but his way of teaching me English was very, very interesting, it's really understandable, so everything can be covered and then the teacher, so everything can be understood.

Dan also described how his English teachers influenced him to like English when he learned it in school:

Dan: The other thing was the English teacher at that time. When English was firstly introduced, it was quite nice and friendly teacher, that's why.

Mista also mentioned that the teacher should motivate the students:

Mista: In our country we have to realize that some or most of our people, they cannot speak English so sometimesthisbecomesobstacles for those who are studying English because after studying it in school, they go home and they face the community who cannot speak or understand the language they study in school. So, I think again, teachers play an important role by motivating the students to practice alone even though a midst of society don't speak. So again, teachers need to motivate the students to practice themselves even though the society cannot speak and understand the language.

Mien argued that the students should like the teacher first, before they like the subject the teacher was teaching. Mien indicated:

Mien: Outside the learners, the instructor must be, should become a facilitator. In general, most of the students, the learners, they said that they don't like English because, you know what, and they said that my English teacher was very poor, boring and mean. They don't like that way so actually, English teacher should be, because if they do that kind of way, I can guarantee that the students don't like the material, so they must love the teacher first, and then the subject. That's my obsession. So whenever I teach, I try to make, I mean from my way of teaching. I tried to attract them. When they are attracted to me, whatever materials I give them and, it will be accepted by them.

Teachers and resources are again mentioned as important to become successful in English language learning. The teacher had the job of delivering a lesson and making it interesting for the students, as Mista indicated:

Mista: From my point of view as a teacher, an English teacher, first is the material, some material maybe should be reviewed. The resource should be reviewed to make it more contextual, can be applied to daily life because we are talking about language. It has to relate, of course it should have a relation with daily life, can be practiced. And of course, teachers play very important role because in performing the 
material, the good techniques or suitable technique play very important role to make the lesson interesting. Because the first thing, we have to make students interested in learning the language.

In relation to this, Dan said that it was important for the teachers to know what to do and what to teach. He said:

Dan: More importantly, the teachers of the staff, meaning that each of them, they should know what they do, what they are going to teach. Because I think that's very important. If the teacher stands in front of the class, he or she does not know what to do, meaning that the subject he is going to teach was not known fully by the teacher, I am afraid it can influence what the students will get from this instructor or teacher standing in front of the class.

Therefore the content and pedagogical knowledge of teacher is important in making English language teaching a success.

Physical facilities such as an adequatelanguagelaboratory and library also supported the teaching practices as did a supportive administrative system. According to Dan:

Dan: You can have a list to make: physical facilities from the school - language lab, books from the library, and materials that can support the teaching facilities.... And then, from me, generally rules and regulations with the system, within the department, within the faculty, and within the university should support what is going to be done for the students in that case. ... One thing, yes, but we also it should be also being contemplated about that thing from our rector and all his senior staff ... they know what this university needs, to help all the components in the system, otherwise we work in the system but with a very shortage of resources and things

The role of the government in making teaching practices successful was also mentioned by Mista:

Mista: I think the government can contribute something, in this case, let's say by training to teachers new techniques of teaching English that can improve the quality of teachers in teaching English. The most important

thing is how to make the teachers awarethatinteachingthelanguage we need to be more creative in order to make the students interested in the language, let's say more professional. To Training and research, I think the government can support.

Dan: $\ldots$ and it means government's responsibility to provide the university needs.

\section{Key Theme: Individual Factors}

The third key theme, individual factors, included personal opinions and attitudes towards English, including motivation.

\section{Student Data}

When the student participants were asked about their first impressions of English, they described English sounds as strange. Helly and Deysa said:

Helly: I think, that the strange sounding ... because it's not my own language, so for the first time, I felt it's so strange ...

Deysa: Honestly speaking, I like English very much when I was still child 
because English is a second language, it is very different from my native language, Talaud or Manadonese so it is something new ... especially the sound is very strange and interesting.

Deysa continued actively in English-related activities. In her narrative, she mentioned about the activities she was involved when she was in senior high school.

Deysa: When I was I senior high school, my English teacher appointed me to participate in English speech competition. It was held in our capital regency, Tahuna. I could get the first winner for three times, in my first, second and third grade. Our school once was invited to be a participant in the Resurrection Day's exhibition in Tahuna. At the time, we did G $30 \mathrm{~S}$ PKI event by drama. It was a nice experience.

She was selected to represent her school in the English speech competition held in the capital regency and was the winner three years in a row.

These participants had various high school backgrounds. Helly was from a language program because she liked to learn languages:

Helly: because I like English very much so I took language program

She also said that she wanted to master English, that reason brought her to study in the English department. When she started her study in the English department, she did not intend to be a teacher, later on when she has involved actively in academic and non academic activities she gradually changed her mind. At the time of the interview, when she was at the final year of study, she was confident about choosing the teaching profession as her future career:
Helly: I like to master the English well

Nihta: just for yourself, or

Helly: no,

Nihta: so what? Sorry

Helly: because I want to be a teacher

Nihta: so you want to be a teacher

Helly: so I want to apply my knowledge to my students.....

Helly: well, for the first time, I don't want to be a teacher because I think that teacher is a difficult job

Nihta: aha

Helly: it is so difficult to guide the students to understand the language but I think when I study in English department UNIMA, I like to be a teacher

Nihta: do you like teaching children or adolescents or adults?

Helly: I like teaching children

Unlike Helly who has been in a language track since high school, Deysa chose the Natural sciences program for expediency reasons, although she also liked English:

Deysa: Honestly, I was interested in studying Biology and English and then I chose Natural program. Because I think, if I chose Natural sciences I can choose either Natural sciences or social sciences or languages when I took a test form university.

She spent a year studying different subjects before she moved to the English department. She elaborated her reason to move to the English department in the following extract:

Deysa: Honestly, I would like to be a doctor. I followed the test of UMPTN twice but I was failed. Because English is very interesting then I chose to take English. When I failed for the first time, I accepted the offer of T2 program (a program offered 
by Sam Ratulangi University to select outstanding high school students based on their academic records to study in this university without taking the entrance test) and entered the Civil Engineering faculty. On the $3^{\text {rd }}$ semester in CE faculty I moved to the English department. After a long consideration, I talked to my father, and you know in the CE faculty it usually takes long time to finish the study and my IP (GPA) is not so good, it's just average 2 point something. Maybe that's the reason. And I think I can do more if I take English in IP (GPA).

She then moved to the English department and became one of the outstanding students in her class. When asked about her plans after university, she said:

Deysa: Get a good job and good salary.

Nihta: Any idea of what job?

Deysa: I haven't made up my mind. Probably being a teacher or a challenging job, the job which offer good salary such as in private company.

Yenta decided to study in the English department because she liked English and wanted to be a teacher:

Yenta: Because I'm interested in studying English. For the future I'd like to be an English teacher.

Another reason to study English further was regarding the status of English.

Helly: English is an international language, so it's good to learn the language most people use when communicating each other. People use English to communicate something ... I think it is a modern time, globalization era, so English is needed in trade, free trade.
Yenta: because English is an international language. I would like to communicate with the seconders

When examining the student data further in order to identify factors that contribute someone to become a good English language learner and factors that constitute successful English teaching practices, factors related to attitude and self motivation were identified, for example:

Helly: I think it depends on the person, whether the person likes to learn English or not.

Deysa: I think self motivation. I mean it should come from the person him or herself.

Above, Deysa mentioned about self-motivation. Motivation from parents and teachers was also indicated as another important factor as described under the previous key themes. Attitudes and motivation were also discussed by the lecturers under this theme, individual factors.

\section{Lecturer Data}

Mien found English very interesting, as she said "it was very new for me and it was the first experience in my life knowing English", and she found it very easy to memorize the words. Having a positive attitude towards English also helped her learning as she described her experience in a vocational high school:

Mien: ... after finishing my study in junior high school, I came to the Teacher's Training School (SPG), and you can imagine the portion of English in school is very small comparing to general high school. They still have more hours in English subject. I still remember in our class, we only learn English once a week. It's 
very poor English because only once a week comparing to high school, they have 4 to 6 hours in a week. And then my English teachers were,... I don't know why but maybe this is already formed in the years before, so you know, I'm insist on learning and learning, knowing and knowing English even though I was taught by the teachers who are not very capable of making the students able to speak English...

She indicated that her experience with English in elementary and junior high schools left a very good memory in her mind and shaped a special bond with English, which later influenced her life-direction decision. She argued that it was probably the very basic motivation in her life:

Mien: (laugh). I don't know why, maybe it's also the motivation, yet the very basic motivation in my life in, ahhh, what is it? anxious to know English. Yeah, I was very anxious to know English because, yeah, for me, I told you that, it was very, very interesting. I do like English as that time...

After she finished the teacher training school, she decided to continue in the English department. Because she had such a strong commitment, she was able to finish her study and then became one of the teaching staff in the same department.

Drawing from her own experience, Mien mentioned that motivation from the learner is important in contributing to being successful in learning English, as she said:

Mien: I think, the first thing must be from himself or herself, a motivation. Because if the learner doesn't have his or her motivation it's quite, it can be but it will be, say, it'll take time. If there is already motivation in the learner, everything, whatever way can be created by himself or herself. It's self motivation.

Mista also mentioned "curiosity and then motivation, self motivation" as important factors to be successful in learning English. Although at first he had the impression that English "was a difficult language, very confusing and everything sounds strange", Mista said that he decided to study English further after he realized the importance of English:

Mista: Yeah. When we were asked to determine which program students had to join, my headmaster was suggesting me to take Science program but I decided to take Language program. Because I am getting interested and I started to realize that the language is more important in the coming times, in the future.

Mista also mentioned that he was motivated by his neighbour, who told him about opportunities to go abroad:

Mista: Also I heard people talking that if you know English you will easily get a job and also most of my neighbours are sailors, even though they're not good at writing they are good at speaking. They also tell us, if you know English you can go abroad easily means you will face a little difficult in the second countries.

Dan believed that attitudes towards English played an important role if someone wanted to be successful: Dan: I think we should, we try to change the attitude of the students. They need to spend more time in the library, meaning that - they have to read 
more about what is going to be covered in class because they're coming from their senior high school where some of or much of the material we taught in the class is not taught during their English classes at their high school. They need to, they have to by the help of their teachers to work or read at home or spend sometime in the library.

Dan focused on the differences in learning style in high school and university and the ability of the students to organize themselves and to change their learning styles. Dan said:

Dan: The way people or students learn in university is different from what they were doing in high school. That's one thing. If they cannot put themselves in the position of university level and I'm afraid they cannot find good opportunity to fill the gap between what they foresee in the future and what they have when they are at the moment, in class ... because frankly speaking, in high school concentrate on vocabulary, structure but for the content subject like literature, language skills, linguistics, they don't have previous experience on that subjects. So they have to change their way of studying, they have to spend more time in the library. It's very difficult to change that kind of habit.

In the university situation in Indonesia, students were expected to do more independent study than when they were in high school. If they could not adjust well with the university situation, it would be devastating for them, if they could cope well, it would lead them to success. Dan also emphasized the motives or reason behind the learning.
He said that if the students considered English as a gateway to get a good job, it would make them study hard. Mista mentioned the same thing:

Mista: As we see in our country, it is important. We can easily get a job, being a secretary, English instructor. In our country it is rare to have someone who knows English well.

Mien suggested that the learner needed to be pro active in order to succeed. She mentioned that since English is considered a second language, which means no daily conversation is performed using English, it is thelearners' responsibility to create a situation where English is always present. The learners, she said, should make use of whatever situation they are in and increase their language skills.

\section{Discussion}

Within the student data, the stories about their initial experiences with English were similar. Each of these student participants had support from the family. The media also, in this case, television, haditsinfluenceinintroducing English through cartoon films to them. These similarities were dependent upon the time in which they grew up. These student participants were introduced to English for the first time when they were at the elementary school level. Growing up with access to technology gave these language learners more opportunity to be in touch with English through mass media such as television and printed papers. They were all surprised by the English sounds they heard when they watched films on TV. The sounds, which were different from their mother tongue. This finding supports the research of Finocchiaro (1964) who stated that childhood is the ideal period to acquire a language. This is based on reasons such as, a lack of inhibition which is typical 
for older learners and a willingness to communicate with their interlocutors without feeling under pressure.

When these student participants started learning English in junior high school they were taught by teachers who had English subject backgrounds. Deysa and Yenta mentioned that at this level they started to like English because of their teacher. They started to become motivated because of the way the teacher taught them.. Unlike Deysa and Yenta, Helly did not mention anything about her English teacher either in junior or senior high school but she did mention about her taking part in the extra courses offered by her English teacher when she was in year one and year three of junior high school. Their first impression of teachers when they were first introduced to English as a second language in a formal school influenced their attitude towards English at more advanced levels of education. The first experience in learning English thus marked their learning English experience and has influenced their decision later in their life.

Despite taking different subject tracks at the senior high school level, all of the participants ended up taking English as their major in the university level. Although their performances differed during their years of study, they were now finishing their studies. Helly felt confident in choosing a language program because she liked languages very well, particularly English. Her earlier experience with English triggered her interest to study English further. She mentioned that at first she did not want to be a teacher because she thought being a teacher was a difficult job. She gradually changed her mind after spending time studying in the English department. She said that she would like to be in the teaching profession, in particular teaching the children. All of the students who took English as their major expressed confidence about both their career choices and about continuing their studies in English even though they were undecided about their future careers.

Deysa who chose a Natural sciences program during high school and spent a year in a civil engineering faculty confidently changed her decision and moved to English department. She was active in the school extra curricular activities as described in her narrative. Although she has not decided yet what kind of job she wants to do, she looked comfortable with her choice. Yenta took a Secretarial program in a vocational high school. Her choice was very much dependent on her parents. After she finished high school, she entered university and chose the English department because she liked English and, again, because her mother suggested she do so. Just like Deysa, Yenta is still not sure whether she will enter the teaching profession or work in a second company after she has finished.

There is one last thing to note in the student data. Although the stories the student participants told were, to some extent, similar, the way in which they responded to the questions was also of interest. It was evident that these students still could not express themselves fully when using English (see the evidence in the transcripts presented). Although before the interview, they were given the option to choose either Indonesian or English, whichever they felt more comfortable with, they all opted for English. Maybe because they wanted to practice their English or perhaps they simply could not say "no English" to me, as they were my English students.

Unlike the student participants' experiences, the lecturer participants 
shared some similarities in their experiences with English: (a) all of them formally started learning English in the first year of junior high school, (b) all of them had shown good performance in English as far as their academic record was concerned, and (c) all of them were English teachers.

The differences, however, exist, not only because they were of different ages but also because they had different community identities which led them holding different opinions.

Dan took his upper level elementary schooling in the early 50s where he had no opportunity to experience English prior to his junior high school years. Mista who attended elementary school in the 80s learned English for the first time from his junior high school friends. On the other hand, Mien, who attended elementary school in the early 70s, had the opportunity to learn English in school when she was in grade 6 . This does not happen very often.

In terms of learning English in school, each of them experienced different education systems and different curricula. When Dan was in senior high school, he learned English only in his first and second year because in year three students concentrated on special subjects that did not include English. The subjects were grouped into Social sciences, Arts, and Sciences classes. Therefore, the examination for the English subject took place at the end of year two. When Mien was in high school, the curriculum that applied was 1975 curriculum. Because Mien was in a teacher training school, the amount of time allocated for English subject was very small based on a consideration that this school was assigned to produce kindergarten and elementary school teachers and English was not taught at this level. Mista, who did his high school studies in the early 90s learned English each year. The proportion of English he studied was even greater in the Language program he chose.

Although these three lecturer participants chose to study English in the university, they had different reasons. Dan said that his high school results showed that he had a very good mark in English subject, so then he decided to continue to study English. Mista indicated that he realized how important English was in order to get a good job, to gain a good living and to have the opportunity to go abroad.

Mien had a rather different perspective, as she said that in addition to her parents wanting her to continue to study in the university, she herself has had a strong interest and motivation since she was first introduced to English in the elementary school.

When answering the research questions, their responses varied. For example, regardingfactorsthatcontribute to successful teaching English practice, all of them mentioned the teacher as an important factor. However, each of them emphasized different points about the teacher. Mista pointed out that it is the job of the teacher to make the lesson interesting. For him, this was considered urgent and therefore a priority. Mien said that the first thing to do is to make the students love the teacher and then they will love the subject. Mien put the emphasis on the performance of the teacher, in attracting the students' interest. And Dan mentioned that it is important that the teachers know what they are going to teach in class, which means good preparation. Dan who has been in English teaching area for more than three decades was able to make a comparison and evaluation of what he did and saw during his career and back 
those opinions with research. Thus, a teacher is considered important and those who are "effective teachers can help learners to progress ... at any level of schooling" (Brumfit 1995).

Students' attitudes were also an important factor. Dan emphasized the importance of students changing their attitudes and learning styles when they are at university if they wanted to be successful. He pointed out that there were differences between learning styles in high schools and universities in Indonesia. Mista and Mien said that the motivation of the students mattered a lot. The differences found in these perspectives are generated from their own experience in teaching English.

\section{Student data vs. Lecturer data}

Most of the participants' first experience with English started when they were around the age of 11 or 12 , involved a family member such as parents, siblings, relatives or friends. But this was not the case for Dan who was introduced to English for the first time in when he started learning it in junior high school and Mien who was fortunate to have a creative teacher in the elementary school, who initiated to teach these grade 6 children English despite its absence in the curriculum. In a number of Gardner studies, parental encouragement was found to be significantly correlated with students' motivation in learning a second language (Gardner, 1983, 1990; Gardner, Masgoret, \& Tremblay, 1999; Gardner et al., 1974).

The participants in this study came from a variety of backgrounds. In spite of these differences, there is one thing shared by most of the participants, the role of parents in the decision making of the children. One argument why this happened is because of the cultural background of the participants. The culture they belong to is very supportive of parents' rights to determine their children's future. In many families in many parts of Indonesia, but specifically in the case of those in North Sulawesi, it is still the practice for parents to impose their own desires and will on their children. This also relates very much to the socio-economic condition of the family. Parents, who have higher incomes, will see themselves having more power to direct their children's future. If what they want is in line with what the children want, there is little or no problem. However, concerns arise when the wants of parents and children do not match.

All of the participants agreed that individual attitudes were important in ordertosucceed.Motivation, self-interest, and positive attitude were mentioned as important factors that should exist to be successful. Crystal (1997) argued that motivation is a central factor in order to successfully learn any second language. Anderson (1961) believed motivation is also a factor that correlates to academic performance. For some researchers, motivation is considered as one of the main determining factors regarding successful in developing second or foreign language learning (Oxford \& Shearin, 1994). However, it is not solely motivation, because there are also other important factors that matter such as family and community.

\section{CONCLUDING REMARKS}

This study explored three key themes generated from the data gathered in this pilot study. These were (1) family and community, (2) institutional influences, and (3) individual factors. These themes were interrelated each other in the context of learning a second language, in particular English in Indonesia. One key question arising from this study remains. This is "Why do some students in the English department 
do better in their English subjects during their first semester at university than other students, given that they bring to the subject a similar number of years of learning English.

The data from the pilot study suggests that various aspects of motivation may influence students learning. Therefore, the purpose of the next stage of this study is to find out the influences on student motivation, [in learning English as a foreign language] performance and subsequently their achievement.

\section{REFERENCES}

Anderson, D. S. 1961. “Non-intellectual Correlates of Academic Performance". VESTES 4(2): 4246.

Brumfit, C., Ed. 1995. Teaching English to Children: From Practice to Principle. Essex: Longman.

Canagarajah, A. S. 1993. "Critical Ethnography of a Sri Lankan Classroom:Ambiguities inStudent Opposition to Reproduction through ESOL". TESOL Quarterly, 27(4), 601-626.

Clyne, M. (Ed.). 1986. An Early Start: Second Language at Primary School. Melbourne: River Seine.

Crookes, G.and Schmidt, R. W. 1991. "Motivation: Reopening the Research Agenda". Language Learning, 41(4), 469-512.

Crystal, D. 1997. The Cambridge Encyclopaedia of Language (Second Ed.). Cambridge: Cambridge University Press.

Dornyei, Z. 1994a. "Motivation and Motivating in the Foreign Language Classroom". The Modern Language Journal, 78(3), 273-284.

Dornyei, Z. 1994b. "Understanding L2 Motivation: On with the Challenge". The Modern Language Journal, 78(4), 515-523.
Ellis, R. 1994. The Study of Second Language Acquisition. Oxford: Oxford University Press.

Ely, C. M. 1986. Language Learning Motivation: A Descriptive and Causal Analysis. The Modern Language Journal, 70(1), 28-35.

Gardner, R. C. 1983. Learning Another Language: A True Social Psychological Experiment. Journal of Language and Social Psychology, 2(2-4), 219-239.

Gardner, R. C. 1990. Attitudes, Motivation, and Personality as Predictors of Success in Foreign Language Learning. In T. S. Parry \& C. W. Stansfield (Eds.), Language Aptitude Reconsidered (pp. 179-221). Engelwood Cliffs, NJ: Prentice Hall Regents.

Gardner, R. C. and Lambert, W. E. 1972. Attitudes and Motivation in SecondLanguage Learning. Rowley, MA: Newbury House.

Gardner, R. C., Masgoret, A. M. and Tremblay, P. F. 1999. Home Background Characteristics and Second Language Learning. Journal of Language and Social Psychology, 18(4), 409-437.

Gardner, R. C., Smythe, P. C., Kirby, D. M., and Bramwell, J. R. 1974. Second Language Acquisition: A Social Psychological Approach (No. Research Bulletin No. 32). Ontario: Ministry of Education.

Krashen, S. D. 1981. Second Language Acquisition and Second Language Learning. Oxford: Pergamon Press.

Labov, W. 1972. "The Transformation of Experience in Narrative Syntax." In W. Labov (Ed.), Language in the Inner City: Studies in the Black English Vernacular. (pp. 354396). Philadelphia: University of Pennsylvania Press. 
Laine, E. J. 1978). “Foreign Language Learning Motivation:Old and New Variables". Paper presented at the 5th Congress of L'Association Internationale De Linguistique Appliquee, Montreal.

Laine, E. J. 1988. The Affective Filter in Foreign Language Learning and Teaching. Report 2: A Validation Study of Filtering Factors with a Focus on the Learner's FL Self-Concept. (No. Jyvaskyla Cross-Language Studies No. 15). Finland: Jyvaskyla University, Dept. of English.

LeBlanc, J. C. 1997. “The Fundamentals of Second-Language Teaching". Mosaic, 5(1), 3-8.

Lin, A. M. Y., Wang, W., Akamatsu, N., and Riazi, M. 2002. „Appropriating English, Expanding Identities, and Re-Visioning the Field: From TESOL to Teaching EnglishfFor Glocalized Communication (TEGCOM)". Journal of Language, Identity, and Education, 1(4), 295316.

Mills, J. 2001. Self-constuction<sic> through Conversation and Narrative in Interviews. Educational Review, 53(3), 285-301.
Morris, F. A. 2001. “Language Learning Motivation for the Class of 2002: Why First-Year Puerto Rican High School Students Learn English". Language and Education, 15(4), 269278.

Norton, B. 1989. “Towards a Pedagogy of Possibility in the Teaching of English Internationally: People's English in South Africa". TESOL Quarterly, 23(3), 401-420.

Norton, B. and Toohey, K. 2001. "Changing Perspectives on Good Language Learners". TESOL Quarterly, 35(2), 307-322.

Oxford, Rand Shearin, J. 1994. “Language Learning Motivation: Expanding the Theoretical Framework". The Modern Language Journal, 78(1), 1228.

Riessman, C. K. 1993. Narrative Analysis (Vol. 30). Thousand Oaks: Sage.

Tremblay, P. F. and Gardner, R. C. 1995. "Expanding the Motivation Construct in Language Learning". The Modern Language Journal, 79(4), 505-520.

White, H. 1973. Meta-history: The historical Imagination in Nineteenth-century Europe. Baltimore: John Hopkins University Press. 